\title{
In vitro force delivery of nickel-titanium superelastic archwires in vertical displacement
}

\author{
Aisha de Souza Gomes Stumpf', Karina dos Santos Mundstock², Daniel Mundstock ${ }^{3}$, Carlos Alberto Mundstock ${ }^{4}$
}

Objective: The purpose of this study was to evaluate the force delivered by different superlastic nickel-titanium wires during vertical displacement, in order to determine whether their stress release meets the criteria for constant and light forces that are usually accredited to these archwires. Method: Ten samples of 6 brands of 0.016 -in archwires (Ormco, GAC, Morelli, TP, American Orthodontics e Rocky Mountain) were tested in a complete metal model using Dynalock brackets ( $3 \mathrm{M}$ Unitek $^{\mathrm{TM}}$ ). In the canine position, there was a sliding bracket connected to a pole. This set was related to a load cell of $0.5 \mathrm{~kg}$ attached to a universal testing machine (Autograph AG-199kNG, Shimadzu). The crosshead speed was $0.5 \mathrm{~mm} / \mathrm{min}$ and the maximum displacement was $1.0 \mathrm{~mm}$. The model was submerged in temperature-controlled water. The results were analyzed by ANOVA $(p<0.05)$, using the software SAS System 8.02, Cry, NC, USA. Results: The TP archwire had the lowest force throughout the test, although the final force was high (277.91 g). The Rocky Mountain archwire had the highest force release (455.41 g). Conclusion: The different brands of wires tested in this study failed in delivering low and constant forces as expected from superlastic nickel-titanium wires. The forces were extremely heavy for a vertical tooth movement.

Keywords: Corrective orthodontics. Orthodontic archwires. Tooth movement.

Objetivo: o objetivo deste estudo foi avaliar a força liberada por diferentes fios de níquel-titânio (NiTi) superelástico em deslocamento vertical, a fim de determinar se a liberação de estresse por esses satisfaz o critério de forças suaves e constantes, geralmente atribuído a tais arcos. Métodos: dez amostras de seis arcos de NiTi superelástico 0,016" de marcas comerciais diferentes (Ormco, GAC, Morelli, TP, American Orthodontics e Rocky Mountain) foram testados em um modelo metálico usando braquetes Dynalock (3M Unitek). Na região do canino, havia um braquete móvel conectado a uma haste, a qual estava relacionada com uma célula de carga de 0,5kg de uma máquina universal de ensaios (Autograph AG-199kNG, Shimadzu). O deslocamento do conjunto na região do canino foi realizado a uma velocidade constante de $0,5 \mathrm{~mm} / \mathrm{min}$ e o deslocamento máximo foi de $1,0 \mathrm{~mm}$. O conjunto foi submerso em água com temperatura controlada a $37^{\circ} \mathrm{C}$. Resultados: os resultados obtidos foram avaliados por ANOVA (p <0,05), usando o software SAS System 8.02, Cry, NC, EUA. O arco da TP apresentou a menor força durante todo o teste, embora a força final tenha sido elevada (277,91g). O fio da Rocky Mountain demonstrou a maior liberação de força $(455,41 \mathrm{~g})$. Conclusões: conclui-se que todas as diferentes marcas comerciais testadas nesse estudo falharam em liberar forças baixas e constantes, como é esperado nos fios de níquel-titânio superelástico. As forças foram extremamente pesadas para o movimento vertical de dentes.

Palavras-chave: Fios ortodônticos. Ortodontia corretiva. Movimento dentário.

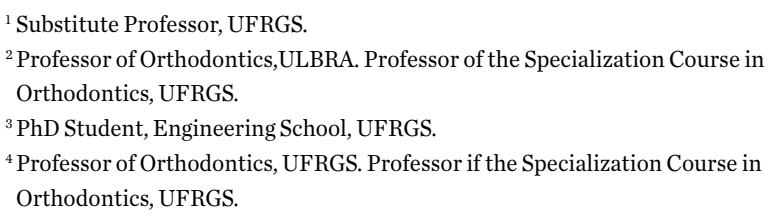

Submitted: August 8, 2008 - Revised and accepted: November 24, 2008

\footnotetext{
How to cite this article: Stumpf ASG, Mundstock KS, Mundstock D, Mundstock CA. In vitro force delivery of nickel-titanium superelastic archwires in vertical displacement. Dental Press J Orthod. 2012 Nov-Dec;17(6):26-30.

" The author reports no commercial, proprietary or financial interest in the products or companies described in this article.

Contact address: Aisha de Souza Gomes Stumpf

Rua Carazinho, 652/302, Petrópolis - Porto Alegre / RS - CEP: 90.460-190 - Brazil E-mail: aishastumpf@terra.com.br
} 


\section{INTRODUCTION}

Orthodontic wires are part of the active elements of fixed orthodontic appliances, being extremely important to the orthodontist because they are basic and essential materials in orthodontic practice. Their mechanical properties are crucial for the type of movement they will provide.

The nickel-titanium wires were developed in order to obtain lighter and constant forces. Today, one can find in the market three basic types of nickeltitanium archwires: The conventional alloy, the superelastic nickel-titanium and the thermoactivated nickel-titanium.

The superelastic nickel-titanium wires perform the same amount of force, regardless of the degree of activation. ${ }^{1}$ The explanation for this behavior is the reversible transformation from the austenite phase, in the passive material, to a martensitic phase by applying stress. This transformation generates constant forces in a wide range of displacement. ${ }^{8}$ The phenomenon of superelasticity is only observes in wires denominated active, which received a suitable thermal treatment for this purpose. ${ }^{9}$ These wires present shape memory returning to their pre-formed shape after deformed.

Due to the maximum force released by these arcs are limited, undesirable effects such as pain, hyalinization and root resorption are prevented. ${ }^{16}$ Bishara ${ }^{1}$ reports that superelastic nickel-titanium wires present biomechanical advantages in orthodontic treatment over other wires, especially when greatly deflected, with minimal permanent deformation, reducing the number of appointments required. The gentle force exerted by truly superelastic wires results in a movement 1.8 times faster when compared to conventional nickel-titanium wires during the initial stages of orthodontic treatment. ${ }^{19}$ The rigidity can also be reduced without changing the size or the shape of the wire. ${ }^{11}$

Not always the superelastic nickel-titanium wires present, in the clinical practice, the constant characteristics of force release. ${ }^{6,10}$ According to Segner and Ibe $^{16}$ most of the superelastic nickel-titanium archwires do not prevent the application of excessive forces. One should also note that the superelastic properties initiate after a minimum activation of $2 \mathrm{~mm}$, which indicates that the superelastic wires are useful for severe irregularities. ${ }^{14,18}$
The aim of this work is to study different brands of superelastic nickel-titanium wires in order to determine the force delivered in a displacement of $1 \mathrm{~mm}$.

\section{MATERIALS AND METHODS}

Ten specimens from six types of circular crosssection (0.016-in) wires were used. The commercial brands were tested: Ormco, GAC, Morelli, TP, American Orthodontics and Rocky Mountain (Table 1).

The wires were tested using a complete maxillary arch model made of stainless steel (Fig 1). The choice of this test model considered that the force exerted by the wire in a tooth is influenced by the friction between the wire, the bracket and the elastic ligature; and therefore, a three-point test would not take simulate the distribution of friction force among the various brackets in a dental arch.

Table 1 - Commercial brands tested.

\begin{tabular}{cc}
\hline COMMERCIAL NAME & BRAND \\
\hline Sentalloy & GAC Int., Bohemia, NYC, USA \\
Morelli Superelástico & Morelli, Sorocaba, Brazil \\
Orthonol & Rocky Mountain, Denver-Co, USA \\
Reflex & TP Ortho, LaPorte-IN, USA \\
Ormco Superelastic & Ormco, Orange-CA, USA \\
Force One superelastic titanium & American Orthodontics, \\
memory wire & Sheboygan-Wi, USA \\
\hline
\end{tabular}

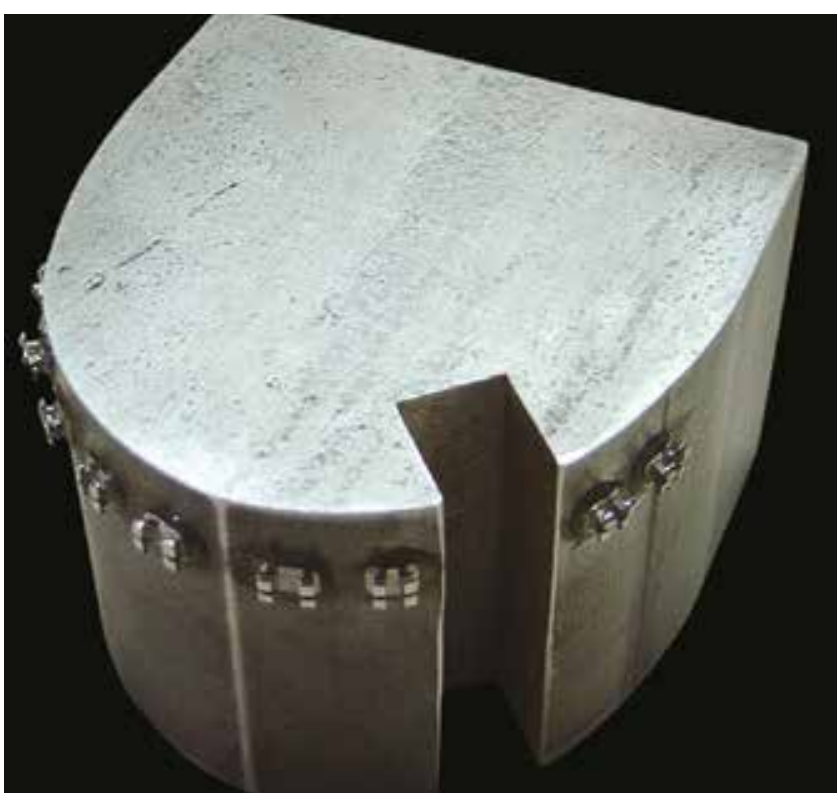

Figure 1 - Stainless steel model used in the test 
Dynalock standard brackets with channel of 0.018-in (3M Unitek ${ }^{\mathrm{TM}}$, St. Paul, USA) were used, which do not generate moment in the wire, thus avoiding the twisting movement. They were bonded with plastic adhesive (Araldite ${ }^{\circledR}$ Brascola, Joinville, Brazil) to the model respecting distances considered average between the different teeth. Where the canine bracket would be located, there was a sliding bracket with a rod connected to a load cell of $0.5 \mathrm{~kg}$ that in turn is attached to a universal testing machine (Autograph AG-199kNG, Shimadzu', São Paulo, Brazil). The universal testing machine applied a displacement with constant cross head speed of $0.5 \mathrm{~mm} / \mathrm{min}$. The maximum displacement was $1.0 \mathrm{~mm}$. Each wire sample was activated and deactivated three times. For data analysis, the displacements were analyzed in 10 blocks with displacement from $0.05 \mathrm{~mm}$ to $1 \mathrm{~mm}$, increasing $0.10 \mathrm{~mm}$ in each block. Thus we have Block 0 with displacement of $0.05 \mathrm{~mm}$, Block 1 with $0.15 \mathrm{~mm}$, Block 2 with $0.25 \mathrm{~mm}$ and so on (Table 2).

In order to measure the displacement of the wire, an inductive displacement sensor (LVDT) was connected to the rod so that the deformation experienced by the load cell during the application of force does not result in an error in measurement by the universal testing machine, considering that the distances studied are extremely small.
To ensure that all wires were tested at a constant temperature, the model was then immersed in water and the temperature controlled by a thermostat (INOVA, Caxias do Sul, Brazil) with NTC sensor and resistance. The reason for the use of water is to avoid the appearance of great convection currents which arise with air, tampering the temperature measurement.

The results were subjected to statistical analysis of variance (ANOVA). The differences between the commercial brands were compared for each displacement.

\section{RESULTS}

The results found are shown in Table 3 . The results were evaluated by comparing the release of energy from each commercial brand at the same displacement. Throughout the test, TP Orthodontics wire had the lowest energy released, starting at $13.84 \mathrm{~g}$ in block 0 , to in $277.91 \mathrm{~g}$ at the end of the test. The arc of RM began with the second lowest energy released, but soon the block 3 had the third largest load released $(141.16 \mathrm{~g})$ and at the end of the test released a force of $455.4 \mathrm{~g}$. In block 0 , the arc with the greatest release of force was from Morelli (24.59 g), but it ended the experiment with a release of $341.94 \mathrm{~g}$ of energy, being the third smallest force.

Table 2 - Displacements in relation to the force measurement points (Blocks).

\begin{tabular}{cccccccccccc} 
Block & $\mathbf{0}$ & $\mathbf{1}$ & $\mathbf{2}$ & $\mathbf{3}$ & $\mathbf{4}$ & $\mathbf{5}$ & $\mathbf{6}$ & $\mathbf{7}$ & $\mathbf{8}$ & $\mathbf{9}$ \\
\hline Displacement $(\mathrm{mm})$ & 0.05 & 0.15 & 0.25 & 0.35 & 0.45 & 0.55 & 0.65 & 0.75 & 0.85 & 0.95 \\
\hline
\end{tabular}

Table 3 - Average of stress released by different commercial brands in the test blocks and comparison of values among the commercial brands in the same displacement.

\begin{tabular}{|c|c|c|c|c|c|c|}
\hline Block & TP & Rocky Mountain & American Orthodontics & Morelli & Ormco & GAC \\
\hline 0 & $13.84^{\mathrm{a}}$ & $20.55^{a}$ & $21.86^{b}$ & $24.59^{c}$ & $23.11^{d}$ & $20.69^{a b}$ \\
\hline 1 & $42.82^{a}$ & $59.78^{b}$ & $63.53^{c}$ & $63.42^{d}$ & $53.32^{\mathrm{e}}$ & $55.27^{f}$ \\
\hline 2 & $69.02^{a}$ & $98.17^{b}$ & $102.31^{c}$ & $92.78^{d}$ & $77.20^{e}$ & $83.81^{\dagger}$ \\
\hline 3 & $95.14^{\mathrm{a}}$ & $141.16^{b}$ & $143.60^{c}$ & $119.59^{d}$ & $100.10^{e}$ & $112.01^{f}$ \\
\hline 4 & $121.71^{\mathrm{a}}$ & $187.43^{b}$ & $185.90^{c}$ & $147.68^{d}$ & $126.45^{\mathrm{e}}$ & $140.12^{f}$ \\
\hline 5 & $149.55^{\mathrm{a}}$ & $239.00^{b}$ & $230.29^{c}$ & $178.81^{d}$ & $161.77^{e}$ & $170.16^{f}$ \\
\hline 6 & $179.04^{a}$ & $292.53^{b}$ & $275.24^{c}$ & $211.30^{d}$ & $205.44^{\mathrm{e}}$ & $204.93^{f}$ \\
\hline 7 & $210.03^{\mathrm{a}}$ & $349.97^{b}$ & $322.21^{c}$ & $250.78^{d}$ & $251.32^{\mathrm{e}}$ & $244.72^{f}$ \\
\hline 8 & $243.21^{\mathrm{a}}$ & $408.87^{b}$ & $369.57^{c}$ & $294.16^{d}$ & $297.50^{\mathrm{e}}$ & $285.38^{f}$ \\
\hline 9 & $277.91^{\mathrm{a}}$ & $455.41^{b}$ & $415.43^{c}$ & $341.94^{d}$ & $345.56^{\mathrm{e}}$ & $326.06^{f}$ \\
\hline
\end{tabular}

* Different letters represent significant statistic difference $(p>0.05)$. 


\section{DISCUSSION}

The results showed that different wires released very different forces. It can be stated that the properties of a material are the result in a first instance of its chemical bonds at the atomic level. ${ }^{7}$ However, the final properties are also the result of interactions that occur between different phases (crystalline or not) that lead to the definition a microstructure of the material. ${ }^{78}$ Bouraruel, ${ }^{4}$ in 1997, reported superelastic nickel-titanium wires with different behaviors due to variations of manufacturers. Likewise, Tonner and Waters ${ }^{18}$ found differences of up to $600 \%$ in the release of energy by superelastic nickel-titanium wires of the same diameter of different manufacturers due to differences in the manufacturing process. The 0.016 superelastic nickel-titanium wire from TP showed the lowest force during the displacement, although the force released at maximum displacement was high $(277.91 \mathrm{~g})$. The wire with the highest release of force at maximum displacement was the Rocky Mountain wire (455.41 g), but during the early stages of the experiment the same wire released less force than some other wires. All wires tested in this study released very high forces for the vertical movement of a canine.

According to Burstone ${ }^{5}$, the ideal force is the one that generates the greatest amount of movement, being the most biological possible, generating minimum discomfort to the patient and minimal undesirable side effects. It is known that the amount of applied force is related to the degree of radicular resorption. ${ }^{15}$ The force considered ideal for tooth movement is still very contradictory. Classic studies suggest the use of forces between 100 and $200 \mathrm{~g}^{2,17}$
However, Ren et $\mathrm{al}^{13}$ and Böhl ${ }^{3}$ claim there is no scientific basis in order to determine an ideal force for orthodontic movement of teeth. The difficulty in conducting studies and the impossibility of calculating the force and tension distribution makes most of the existing studies show methodological flaws., ${ }^{3,13}$

It was noted in this study that, considering a small displacement, superelastic nickel-titanium wires do not show this behavior, as evidenced fairly large increase in the release of force during the displacement. Tonner and Waters ${ }^{18}$ also found similar results, in which the force released by superelastic wires was too high reaching $146 \mathrm{cN} / \mathrm{mm}$. Noting that these authors have tested the relationship between the release of energy of superelastic wire and temperature. Other authors reported the same situation. ${ }^{6,10,12,16}$ However, it should be emphasized that any comparison with other studies' results should be undertaken with caution due to the fact that the methodology used in this experiment differs from other studies in the literature. This methodology was chosen to generate results more similar to the clinical performance of wires, since the three-point test recommended by ADA does not represent the reality of friction and force to which orthodontic arches are subjected.

\section{CONCLUSION}

The different brands tested in this study did not deliver constant force during a vertical displacement of $1 \mathrm{~mm}$. The forces released by all the wires tested were very high for orthodontic movement, ranging from $277.91 \mathrm{~g}$ and $455.41 \mathrm{~g}$ depending on the commercial brand tested. Thus, the effect of superelasticity in small vertical displacements has not been proven. 


\section{REFERENCES}

1. Bishara SE, Winterbottom JM, Sulieman AH, Rim K, Jakobsen JR. Comparisons of the thermodynamic properties of three nickel-titanium orthodontic archwires. Angle Orthod. 1995;65(2):117-22.

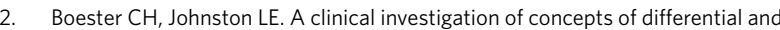
optimal force in canine retraction. Angle Orthod. 1974;44(2):113-9.

3. Von Böhl M, Maltha J, Von den Hoff H, Kuijpers-Jagtman AM. Changes in the periodontal ligament after experimental tooth movement using high and low continuous forces in beagle dogs. Angle Orthod. 2004;74(1):16-25.

4. Bourauel C, Drescher D, Ebling J, Broome D, Kanarachos A. Superelastic nickeltitanium alloy retraction springs. An experimental investigation of force systems. Eur J Orthod. 1997;19(5):491-500.

5. Burstone CJ. Variable-modulus orthodontics. Am J Orthod. 1981;80(1):1-16.

6. Filleul MP, Jordan L. Torsional properties of Ni-Ti and Copper Ni-Ti wires: the effect of temperature on physical properties. Eur J Orthod. 1997;19(6):637-49.

7. Flores DA, Caruso JM, Scott GE, Jeiroudi MT. The fracture strength of ceramic brackets: a comparative study. Angle Orthod. 1990;60(4):269-76.

8. Kapila S, Sakima T, Miyazaki S, Sachdeva R. Ligas ortodônticas correntemente em uso. Revisão (parte I). Rev Odontol Univ São Paulo. 1990;4(4):334-42.

9. Kusy RP, Wilson TW. Dynamic mechanical properties of straight titanium alloy archwires. Dent Mater. 1990;6(4):228-36.

10. Meling TR, Odegaard J. On the variability of cross-sectional dimensions and torsional properties of rectangular nickel-titanium arch wires. Am J Orthod Dentofacial Orthop. 1998;113(5):546-57.
11. Mullins WS, Bagby MD, Norman TL. Mechanical behavior of thermo-responsive orthodontic archwires. Dent Mater. 1996;12(5):308-14

12. Nakano H, Satoh K, Norris R, Jin T, Kamegai T, Ishikawa F, et al. Mechanical properties of several nickel-titanium alloy wires in three-point bending tests. Am J Orthod Dentofacial Orthop. 1999;115(4):390-5

13. Ren Y, Maltha JC, Kuijpers-Jagtman AM. Optimum force magnitude for orthodontic tooth movement. A systematic literature review. Angle Orthod. 2003;73(1):86-92.

14. Rock WP, Wilson HJ. Forces exerted by orthodontic aligning archwires. Br J Orthod. 1988;15(4):255-9.

15. Santos ECA, Lara TS, Arantes FM, Coclete GA, Silva RS. Análise radiográfica computadorizada da reabsorção radicular apical após a utilização de duas mecânicas ortodônticas. Rev Dental Press Ortod Ortop Facial. 2007;12(1):48-55.

16. Segner D, lbe D. Properties of superelastic wires and their relevance to orthodontic treatment. Eur J Orthod. 1995;17(5):395-402.

17. Storey E, Smith R. Force in orthodontics and its relation to tooth movement. Aust Dent J. 1952;56(1):11-8

18. Tonner RI, Waters NE. The characteristics of superelastic Ni-Ti wires in the threepoint bending. Part I: the effect of temperature. Eur J Orthod. 1994;16(5):409-19.

19. Warita H, lida J, Yamaguchi S, Matsumoto Y, Fujita Y, Domon S. A study on experimental tooth movement with Ti-Ni alloy orthodontic wires: comparisons between light continuous and light dissipating force. J Jpn Orthod Soc. 1996;55:515-27. 